\title{
A Case Report: Radiation-Induced Kidney Cancer after Treatment for Cervical Cancer
}

\author{
Berrin Inanc ${ }^{1 *}$, Kubilay Inanc ${ }^{2}$ and Birsen Yucel $^{2}$
}

${ }^{1}$ Department of Radiation Oncology, S.B.Ü. Istanbul Education Research Hospital, Istanbul, Turkey

${ }^{2}$ Department of Radiation Oncology, Şişli Hamidiye Etfal Education and Research Hospital, Istanbul, TR-34377, Turkey

"Corresponding author: Berrin Inanc, Department of Radiation Oncology, S.B.Ü. Istanbul Education Research, Hospital Istanbul, Turkey, Tel: 902124596692; E-mail: byalcin77@hotmail.com

Received date: August 01, 2018; Accepted date: August 20, 2018; Published date: August 24, 2018

Copyright: (c) 2018 Inanc B, et al. This is an open-access article distributed under the terms of the Creative Commons Attribution License, which permits unrestricted use, distribution, and reproduction in any medium, provided the original author and source are credited.

\begin{abstract}
Radiotherapy treatment for cervical cancer may cause secondary cancer within both surrounding organs and those farthest away. Here we report a case report of kidney cancer developed after curative radiotherapy treatment for cervical cancer which was detected with Computerized Tomography (CT) five years later.
\end{abstract}

Keywords: Cervical cancer; Radiotherapy; Kidney cancer; Treatment; Positron emission tomography

\section{Introduction}

Treatment of cervical cancer usually succeeds so that cervical cancer has become a survivable disease with a large population of long-term survivors [1]. On the other hand, during radiation therapy in cervical cancer, many organs can be affected. According to distance of organ to cervix, radiotherapy results in organ doses that range from thousands of cGrays to tens of cGrays. Radiotherapy may cause second primary cancers after treatment of cervical cancer in heavily irradiated sites (dose $>3 \mathrm{~Gy}$ ) such as colon, rectum, uterus, ovary, vagina, bladder, bone; in moderately irradiated sites $(1 \mathrm{~Gy}<\mathrm{dose}<3 \mathrm{~Gy})$ such as liver, stomach, pancreas, kidney; in lightly irradiated sites (dose<1Gy) such as esophagus, lung, breast, thyroid [2].

Here we report a case of radiotherapy induce secondary kidney cancer after treatment of cervical cancer patient.

\section{Case Report}

A 50-years-old woman who was in menopause status for 3 years was admitted to our hospital because of vaginal bleeding in 2010. Physical examination of a $5 \mathrm{~cm}$ mass which invaded whole portion and $1 / 3$ upper vagen. After curatage biopsy, we detected non-keratinize squamous cell cancer of cervix. No distant metastasis were revealed through a thorough evaluation including Magnetic Resonance Imaging (MRI) and Fluorine-18- Fluorodeoxyglucose Positron Emission Tomography (F-18 FDG PET/CT). Stage was IIA and the treatment was concomittant chemoraditherapy. (Cisplatin $60 \mathrm{mgr} / \mathrm{week}$ and whole pelvis $25 \times 180 \mathrm{cGy} / 45 \mathrm{~Gy}$ and $5 \times 6$ Gy total 30Gy intracaviter radiotherapy) Subsequently the patient did well and follow-up ensued negative.
Five years later, she had gross hematuria. A $2.5 \mathrm{~cm}$ right kidney mass was detected in CT (Figure 1). She underwent right nephrectomy and pathology result was renal cell carcinoma. She had no adjuvant therapy. We revived her previous radiotherapy doses and we realized that in the Dose-Volume Histogram (DVH), received dose of right kidney was $0.58 \mathrm{~Gy}$ (Figure 1).

\section{Discussion}

Radiotherapy has an important role in the treatment of various cancers although it has many side effects. One of them is second primary cancer. The risk of second cancer development with cervical cancer evaluated in cohort and case-control studies [3-7]. Radiation treatment for cervical cancer contains external beam radiotherapy, brachytherapy or combination of both modalities. In our case according to the stage the choice was combination of both modalities. In the pelvic region organs received very high doses of radiation (>30Gy) such as colon, rectum, ovaries. Organs in the abdominal cavity such as kidney, stomach, received between 1 and 3 Gy. (Table 1 shows the range of doses).

In the cohort study, the organs which were receiving between 1 and $3 \mathrm{~Gy}$, only the risk for cancer of the kidney was significantly increased among irradiated 30-year survivor who was accompanied by a trend of increasing over time [2].

Excess cancer incidence was seen in the lung, other genital organs, bladder and rectum which were close to cervix except lung after treatment of cervical cancer with radiotherapy [3].

There was a decreased incidence of breast cancer in irradiated patients. It might depend on ovarian ablation by radiotherapy [8]. But in other study, there was an increased risk in breast cancer [9]. 
Citation: Inanc B*, Inanc K and Yucel B (2018) A Case Report: Radiation-Induced Kidney Cancer after Treatment for Cervical Cancer. J Integr

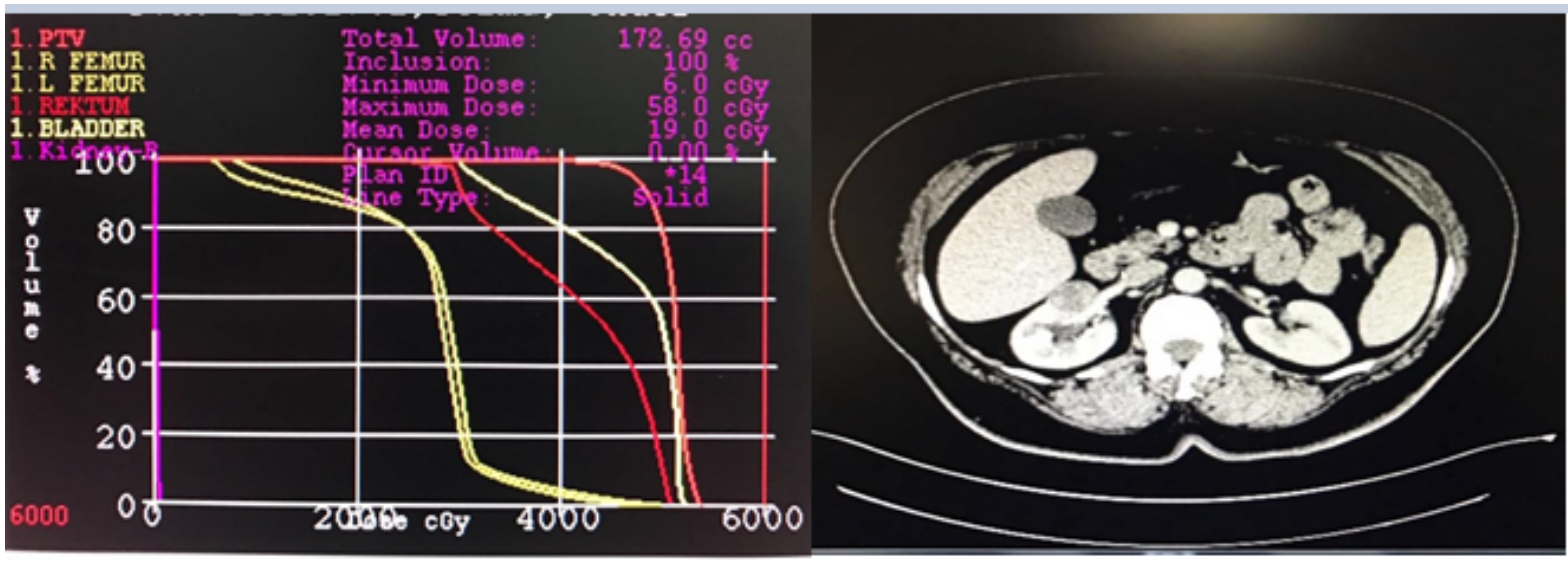

Figure 1: Dose-Volume Histogram (DVH) of right kidney.

\begin{tabular}{|l|l|}
\hline Second cancer & Average organ dose (Gy) \\
\hline Heavily irradiated site (dose>3 Gy) & Oct-20 \\
\hline Small Intestine & 24 \\
\hline Colon & $30-60$ \\
\hline Rectum & 165 \\
\hline Uterus & 32 \\
\hline Ovary & 66 \\
\hline Vagina & $30-60$ \\
\hline Bladder & 22 \\
\hline Bone & 7 \\
\hline Connective Tissue & \\
\hline Moderately irradiated site (1 Gy<dose<3 Gy) \\
\hline Liver & 2 \\
\hline Stomach & 2 \\
\hline Pancreas & 2 \\
\hline Kidney & 2 \\
\hline Lightly irradiated site (dose <1 Gy) & 0.3 \\
\hline Esophagus & 0.3 \\
\hline Lung & 0.1 \\
\hline Breast & \multicolumn{2}{|l|}{} \\
\hline Thyroid & \\
\hline From Boice, et al. [5] & \\
\hline & \\
\hline
\end{tabular}

In recent years there have been technological advances in imaging, computer treatment planning systems and linear accelerator technology. Intensity Modulated Radiotherapy (IMRT) was becoming more widely available. This modality showed improvement over the conventional treatment technique with reduced dose to pelvic organs $[10,11]$. However, the estimated increase in second cancer risk was $6 \%$ for 6-mv IMRT and $26 \%$ for $18 \mathrm{mv}$ IMRT, with large increases in organs away from the primary beam and skin because with IMRT a much larger volume of skin was exposed [12].

CT based treatment planning with conformal blocking and dosimetry was very important for external beam radiotherapy. ConeBeam CT (CBCT) may be helpful in defining daily internal soft tissue positioning. Image-based volumetric brachytherapy approaches using CT, USG can be used more widely.

The risk of late effects of cervical cancer treatment with radiotherapy is related to the volume, total doses, dose per fraction and specific intrinsic radio-sensitivity of the normal tissue that was irradiated [13-15]. Careful blocking is very important to protect organs at risks exposure, even organs which are far from pelvic region.

\section{Conclusion}

Comparisons of organ-specific equivalent with conventional IMRT, preferring scattering mode in proton therapy is claimed to be either significantly lower or, at least, does not exceed the risk of estimated secondary cancer [16].

\section{References}

1. CM F (1992) Cervix uteri. In: Miller BA, Gloekler Ries LA, Hankey BF, Kosary CL, Edwards B (eds.). Cancer statistics review (1973-89). NIH publication, Bethesda, MD: U.S. Dept. of Health and Human Services, Vol. 1-7.

2. Kleinerman RA, Curtis RE, Ice JD Jr, Flannery JT, Fraumeni JF (1982) Jr. Second cancers following radiotherapy for cervical cancer. J Nail Cancer Int 69: 1027-1033.

Table 1: Typical average organ doses associated with radiotherapy for cervical cancer.

3. Boice JD Jr, Day NE, Andersen A, Brinton LA, Brown R, et al. (1985) Second cancers following radiation treatment for cervical cancer: an international collaboration among cancer registries. J Natl Cancer Inst 74: 955-975. 
Citation: Inanc B*, Inanc K and Yucel B (2018) A Case Report: Radiation-Induced Kidney Cancer after Treatment for Cervical Cancer. J Integr

4. Boice JD Jr, Blettner M, Kleinerman RA, Stovall M, Moloney WC, et al. (1987) Radiation dose and leukemia risk in patients treated for cancer of the cervix. J Natl Cancer Inst 79: 1295-1311.

5. Boice JD Jr, Engholm G, Kleinerman RA, Blettner M, Stovall M, et al (1988) Radiation dose and second cancer risk in patients treated for cancer of the cervix. Radiat Res 116: 3-55.

6. Boice JD Jr, Blettner M, Kleinerman RA, Engholm G, Stovall M, et al. (1989) Dose reconstruction for therapeutic and diagnostic radiation exposures: use in epidemiological studies . K Int J Cancer 44: 7-16.

7. Day NE, Boice JD Jr. (1983) Second cancers in relation to radiation treatment for cervical cancer. IARC Scientific Publication No. 52. Lyon, France 52: 1-207.

8. Hemminki K, Dong C, Vaittinen P (2000) Second primary cancer after in situ and invasive cervical cancer. Epidemiology. 11: 457-461.

9. Wright JD, St Clair CM, Deutsch I (2010) Pelvic radiotherapy and the risk of secondary leukemia and multiple myeloma. Cancer 116: 2486-2492.

10. Hall EJ, Wuu CS (2003) Radiation-induced second cancers: the impact of 3D-CRT and IMRT. Int J Radiat Oncol Biol Phys 56: 83-88.

11. RTOG 1203 Protocol Information (2013) Radiation Therapy Oncology Group.
12. Seidman JD, Kumar D, Cosin JA (2006) Carcinomas of the female genital tract occurring after pelvic irradiation: a report of 15 cases. Int J Gynecol Pathol 25: 293-297.

13. Erickson-Whitmann B, Rownd J, Khater K (2009) Biologic and physical aspects of radiation oncology. In: Barakat R, Markman M, Randall M (eds.) Principles and Practice of Gynecology Oncology. Philadelphia: Lippincott Williams \& Wilkins, pp: 325-380.

14. Forrest JL, Ackerman I, Barbera L (2010) Patient outcome study of concurrent chemoradiation, external beam radiotherapy and high-dose rate brachytherapy in locally advanced carcinoma of the cervix. Int J Gynecol Cancer 20: 1074-1078.

15. Perez CA, Grigsby PW, Lockett MA (1999) Radiation therapy morbidity in carcinoma of the uterine cervix: dosimetric and clinical correlation. Int J Radiat Oncol Biol Phys 44: 855-866.

16. Yoon M, Ahn SH, Kim J, Shin DH, Park SY, et al. (2010) Radiationinduced cancers from modern radiotherapy techniques: intensitymodulated radiotherapy versus proton therapy. Int J Radiat Oncol Biol Phys 77: 1477-1485. 